\title{
KORELASI LAYANAN INFORMASI DIGITAL DENGAN KEMANDIRIAN PESERTA DIDIK JURUSAN ILMU PENGETAHUAN SOSIAL UNTUK MELANJUTKAN STUDI PADA PERGURUAN TINGGI
}

\author{
Septian Aji Permana \\ Universitas PGRI Yogyakarta \\ Email: $\underline{\text { aji@upy.ac.id }}$
}

\begin{abstract}
Info Artikel
Sejarah Artikel:

Diserahkan 12 April 2020

Direvisi 27 April 2020

Disetujui 15 Mei 2020

\section{Keywords:}

digital information services,

independence character,

higher education information

Abstract

This study aims to determine the correlation of digital information services with selfadjustment (independence of character) of students majoring in social studies in obtaining higher education information.

This study uses a quantitative approach. The population of this study was all social studies students of class X. XI, and XII in SMA N 2 Bantul Yogyakarta in 2018/2019 Academic Year, totaling 111 students. Intake by using quota random sampling technique by taking $25 \%$ of the number of class XII students that is a number of 35 students. Data collection methods in this study used a validated questionnaire with logical validity. Data analysis techniques using multiple regression analysis.

The results showed that there was a positive and significant correlation between digital information services and self-adjustment (independence of character) of students majoring in social studies in obtaining higher education information, by knowing the results of the calculation of rxly $=0.741$ with $(P) 0,000<0.01$, which means there is a positive and significant correlation between digital information services and self-adjustment (independence of character) of students majoring in social studies in obtaining higher education information. Implications in this study, schools should provide an intensive digital information service in accordance with the needs of students, so students will have comprehensive information about several aspects that exist in themselves as well as directions about higher education information services that are expected by students in develop their talents, interests, and potentials, so that they will influence and enhance the attitude of independence of good students.
\end{abstract}

\begin{abstract}
Abstrak
Penelitian ini bertujuan untuk mengetahui korelasi layanan informasi digital dengan penyesuaian diri (karakter kemandirian) peserta didik jurusan IPS dalam mendapatkan informasi perguruan tinggi.

Penelitian ini menggunakan pendekatan kuantitatif. Populasi penelitian ini yaitu seluruh peseta didik IPS kelas X. XI, dan XII di SMA N 2 Bantul Yogyakarta Tahun Ajaran 2018/2019 yang berjumlah 111 siswa. Pengambilan dengan menggunakan teknik quota random sampling dengan mengambil $25 \%$ dari jumlah siswa kelas XII yakni sejumlah 35 siswa. Metode pengumpulan data dalam penelitian ini menggunakan angket yang divalidasi dengan validitas logis. Teknik analisa data dengan menggunakan analisis regresi ganda.

Hasil penelitian menunjukan bahwa ada korelasi positif dan signifikan antara layanan informasi digital dengan penyesuaian diri (karakter kemandirian) peserta didik jurusan IPS dalam mendapatkan informasi perguruan tinggi, dengan mengetahui hasil perhitungan angka rx1y $=0,741$ dengan $(\mathrm{P}) \quad 0,000<0,01$, yang berarti ada korelasi positif dan signifikan antara layanan informasi digital dengan penyesuaian diri (karakter kemandirian) peserta didik jurusan IPS dalam mendapatkan informasi perguruan tinggi. Implikasi dalam penelitian ini, sekolah hendaknya memberikan suatu layanan informasi digital secara intensif sesuai dengan kebutuhan peserta didik, maka peserta didik akan memiliki informasi yang komperhensif mengenai beberapa aspek yang ada pada dirinya serta pengarahan mengenai layanan informasi perguruan tinggi yang sesuai dengan yang diharapkan peserta didik dalam mengembangkan bakat, minat, serta potensi yang mereka miliki, sehingga akan mempengaruhi dan meningkatkan sikap kemandirian peserta didik yang baik.
\end{abstract}




\section{PENDAHULUAN}

Berdasarkan pasal 31 Undang-undang Dasar 1945 bahwa pendidikan merupakan suatu keharusan bagi manusia sebagai upaya memanusiakan manusia. Pendidikan juga salah satu hak yang dapat diperoleh bagi semua warga negara Republik Indonesia.

Pasal 6 Tahun 2005 pada UUD, menjelaskan bahwa tujuan pendidikan, yaitu mengembangkan potensi peserta didik agar menjadi manusia yang beriman dan bertakwa kepada Tuhan Yang Maha Esa, berakhlak mulia, sehat, berilmu, cakap, kreatif, mandiri, serta menjadi warga negara yang demokratis dan bertanggung jawab.

Layanan informasi secara umum bermaksud memberikan pemahaman kepada individu-individu yang berkepentingan tentang berbagai hal yang diperlukan untuk menjalani suatu tugas atau kegiatan serta untuk menentukan arah suatu tujuan atau rencana yang dikehendaki (Sjukur et al, 2012). Menurut C. Rajanandhini et al (2019) layanan informasi merupakan layanan bimbingan yang memungkinkan peserta didik dan pihak-pihak lain yang dapat memberikan pengaruh yang besar kepada peserta didik dalam menerima dan memahami informasi (seperti informasi pendidikan dan informasi jabatan) yang dapat dipergunakan sebagai bahan pertimbangan dan pengambilan keputusan sehari-hari sebagai pelajar, anggota keluarga dan masyarakat.

B. Jadhavar et al (2011), menjelaskan bahwa layanan informasi adalah layanan bimbingan dan konseling yang memungkinkan klien menerima dan memahami berbagai informasi (informasi pendidikan, jabatan, karir) yang dapat dipergunakan sebagai bahan pertimbangan dan pengambilan keputusan demi kepentingan individu. Proses pendidikan di sekolah memerlukan peranan penting pendidik yang bertugas membimbing dan membina peserta didiknya. Khususnya di Sekolah Menengah Atas suatu layanan bimbingan dan konseling berupa layanan informasi digital dan layanan penyaluran sangat diperlukan oleh peserta didik karena memiliki fungsi dalam hal pemahaman serta pencegahan (Bade, 2019).

Mendengarkan keluhan para peserta didik IPS di SMA N 2 Bantul, Yogyakarta, bahwa anak-anak IPS selalu dianggap second class, dan ini disebabkan anak-anak ips sendiri kurang dibekali informasi mengenai perguruan tinggi yang komperhensif sehingga karakter kemandirian sangat lemah dibanding dengan rumpun-rumpun ilmu lainnya. Layanan informasi secara digital sangat diperlukan oleh peserta didik IPS supaya anak-anak tahu bahwa jurusan IPS di perguruan tinggi juga memiliki reputasi yang baik salah satu contohnya STAN.

Layanan informasi digital merupakan layanan yang memungkinkan siswa menerima dan memahami berbagai informasi yang dapat digunakan sebagai bahan pertimbangan dalam pengambilan keputusan untuk kepentingan diri sendiri. Pemberian informasi semestinya dilakukan sejak anak memasuki sekolah. Hal tersebut dikarenakan pada masa itu anak masih memiliki pengetahuan yang minim tentang berbagai hal, sehingga informasi apa saja yang diterima akan mempengaruhi sikap mereka (J.M.P. Martinez, 2007).

Layanan informasi digital yang dapat diberikan meliputi, layanan informasi mengenai diri pribadinya, mengenai lingkungannya, pergaulannya, informasi belajar, pendidikan, sosial-masyarakat, serta informasi mengenai jenjang karir ke depan (Maiwinda, et al, 2019). Pemberian layanan informasi yang sesuai dengan kebutuhan siswa akan memberikan pengaruh yang baik terhadap anak, hal tersebut dikarenakan anak akan memahami mengenai beberapa aspek mengenai diri pribadinya sehingga akan berdampak baik terhadap sikap penyesuaian dirinya sebaliknya apabila pemberian layanan informasi yang mereka butuhkan kurang sesuai dengan kebutuhan mereka, maka akan berdampak kepada pemahaman anak yang kurang sesuai pula. Hal tersebut akan mengakibatkan anak sulit menentukan langkah dan arah hidupnya ke depan, sehingga akan berdampak sulitnya anak menyesuaikan diri di lingkungan dia berada.

Peserta didik yang sudah memahami mengenai berbagai informasi, baik tentang dirinya maupun tentang lingkungan masyarakat, maka peserta didik akan dapat menentukan arah hidupnya ke depan, dapat mengambil keputusan secara tepat, bertindak kreatif, mandiri serta dapat menyesuaikan diri dengan lingkungan. Harapannya layanan informasi yang sesuai dengan kebutuhan peserta didik telah diberikan secara intensif, maka dapat dipastikan anak akan mendapatkan suatu layanan penyaluran yang tepat pula. Melalui layanan penyaluran bahwa peserta didik dapat diarahkan untuk mengembangkan bakat, minat, potensi yang dimiliki sesuai dengan kondisi pribadinya, baik akademik maupun non akademik. 
Pelaksanaan layanan penyaluran kepada peserta didik IPS akan mempengaruhi penyesuaian diri mereka. Betapa bahagianya mereka, apabila bakat, minat serta potensi yang mereka miliki dapat tersalurkan secara tepat dan sesuai dengan keinginan mereka. Hal tersebut akan sangat mempengaruhi perkembangan kemampuan anak, sehingga mereka dapat mencapai perkembangan diri secara optimal. Apabila anak dapat mengembangkan diri secara optimal, maka dapat dipastikan penyesuaian diri mereka akan baik.

Namun demikian di SMA N 2 Bantul masih ditemukan beberapa dari peserta didik IPS yang masih kesulitan dalam menentukan arah masa depannya, belum dapat mengambil keputusan secara tepat, belum mandiri, dan sulit mengembangkan bakat, minat serta potensi yang mereka miliki, serta masih sulitnya mereka dalam penyesuaian diri di lingkungan mereka berada. Adanya kesulitankesulitan tersebut dikarenakan pihak sekolah belum optimal dalam memberikan layanan informasi dan layanan penyaluran yang sesuai kebutuhan peserta didik IPS.

\section{METODE PENELITIAN}

Penelitian ini menggunakan pendekatan kuantitatif. Populasi penelitian ini yaitu seluruh peseta didik IPS kelas X. XI, dan XII di SMA N 2 Bantul Yogyakarta Tahun Ajaran 2018/2019 yang berjumlah 111 siswa.

Pengambilan dengan menggunakan teknik quota random sampling dengan mengambil 25\% dari jumlah siswa kelas XII yakni sejumlah 35 siswa. Metode pengumpulan data dalam penelitian ini digunakan angket yang divalidasi dengan validitas logis.

Teknik analisa data dengan menggunakan analisis Bevariat. Adapun rumus yang digunakan adalah korelasi product moment, dengan kriteria penerimaannya yaitu jika nilai koefisien korelasi rxy hitung lebih besar dari atau sama dengan koefisien rxy dalam tabel pada signifikasi $5 \%$. Rumus koefisien korelasi rxy sebagai berikut;

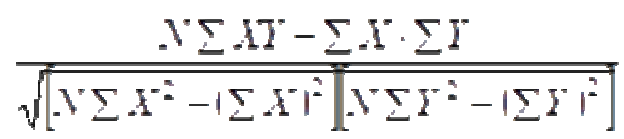

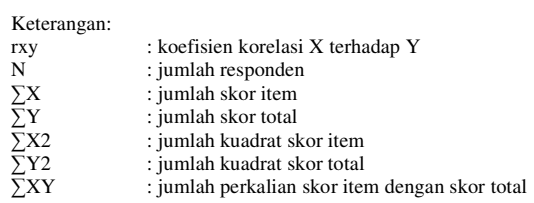

\section{HASIL DAN PEMBAHASAN}

Hasil penelitian diperoleh melalui angket yang disebarkan kepada 35 responden pada peserta didik IPS di SMA N 2 Bantul, Yogyakarta. Skor yang diperoleh dari masingmasing butir pernyataan tiap-tiap variabel ditabulasikan dan dihitung SPSS. Data tentang layanan informasi diperoleh melalui angket yang bersifat tertutup dengan jumlah item sebanyak 19 butir. Adapun skor yang digunakan dalam angket tersebut 1-4 sehingga berdasarkan skor tersebut maka variabel layanan informasi memiliki rentang skor 19-76. Berdasar data induk yang diperoleh dari responden pada penelitian ini diperoleh skor terendah 42 dan skor tertinggi 75.

Berdasarkan tabel distribusi frekuensi data tentang layanan informasi, maka histogram frekuensi data adalah

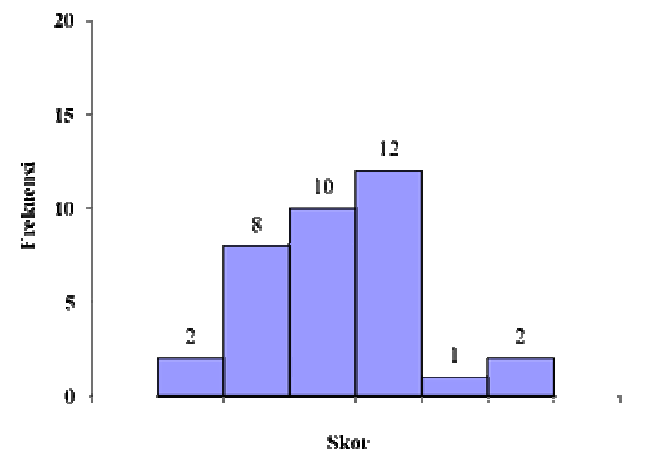

Gambar. Histogram Layanan Informasi

Dengan menggunakan rumus tendensi sentral diperoleh data Mean $(\mathrm{M})=57,8$, Median $(\mathrm{Me})=58$, Modus $(\mathrm{Mo})=62,5, \mathrm{SB}$ $(\mathrm{SD})=7,22$. Selanjutnya skor tersebut dikategorikan untuk pengkategorian gejala yang diamati didasarkan pada nilai terendah, nilai tertinggi dan rata-rata (mean) sehingga diperoleh kategori dari nilai-nilai tersebut. Dari rumus tersebut maka untuk variabel layanan informasi diperoleh rentang nilai $=75-42=33$. Interval kategori $=33: 4=8,25$.

Pengkategorian layanan informasi digital menjadi empat kategori yaitu tidak pernah, kadang-kadang, sering dan selalu. Kategori tersebut didasarkan pada rentang nilai 
dan interval. Dipilihnya empat kategori ini karena distribusi gejalanya berdistribusi normal dan kriteria ini menggunakan jarak pengukuran yang sama. Penggolongannya sebagai berikut:

Tabel kategori layanan informasi digital

\begin{tabular}{|ccc|c|c|l}
\hline \multicolumn{2}{|c|}{ Klas Interval } & Frek. & $\begin{array}{c}\text { Frek. } \\
\text { Persentase }\end{array}$ & Kategori \\
\hline 67 & - & 75 & 2 & 5.71 & Selalu \\
\hline 58 & - & 66 & 16 & 45.71 & Sering \\
\hline 49 & - & 57 & 13 & 37.14 & Kadang-kadang \\
\hline 40 & - & 48 & 4 & 11.43 & Tidak pernah \\
\hline \multicolumn{2}{|c|}{ Jumlah } & 35 & 100 & \\
\hline
\end{tabular}

Sumber : Suharismi, 2010

Berdasarkan tabel di atas, maka dapat dinyatakan bahwa data layanan informasi digital meliputi $11,43 \%$ berada pada kategori tidak pernah, $37,14 \%$ berada pada kategori kadang-kadang, 45,71\% berada pada kategori sering dan $5,71 \%$ berada pada kategori selalu. Dengan demikian dikatakan bahwa data layanan informasi peserta didik IPS di SMA N 2 Bantul, Yogyakarta berkategori sering tetapi masih sebatas informasi umum belum sepesifik mengarah ke perguruan tinggi yang memiliki jurusan IPS ikatan dinas sepeti contohnya STAN.

Data yang sudah didapat lalu peneliti melakukan uji normalitas dengan tujuan yakni untuk mengetahui kondisi masing-masing variabel penelitian apakah variabel tersebut memiliki skor yang berdistribusi normal atau tidak. Adapun teknik yang digunakan dalam uji normalitas ini adalah chi kwadrat (X2). Untuk menguji signifikansi chi kwadrat hasil perhitungan pada penelitian ini menggunakan taraf signifikansi 5\%. Interpretasi hasil uji normalitas adalah jika harga chi kwadrat dengan $\mathrm{p}>0,05$, maka variabel tersebut berdistribusi normal. Hasil uji normalitas sebaran variabel layanan informasi diperoleh chi kwadrat sebesar 5,739 dengan p 0,766 > 0,05, maka data tersebut berdistribusi normal.

Berdasarkan hasil penelitian ini diperoleh setelah memasukan rumus tersebut dalam komputer SPSS didapat harga koefisien korelasi product moment (r) antara layanan informasi (X1) dengan penyesuaian diri (Y) sebesar 0,741 dan nilai $p=0,000$. Hal ini menunjukkan bahwa nilai $\mathrm{p}<0,01$ yang berarti ada korelasi yang positif dan signifikan antara layanan informasi digital dengan penyesuaian diri (karakter kemandirian).
Dari hasil analisis Bevariat didapat harga koefisien korelasi product moment (r) antara layanan penyaluran informasi (X2) dengan penyesuaian diri (karakter kemandirian) (Y) sebesar 0,690 dan nilai $\mathrm{p}=$ 0,000 . Hal ini menunjukkan bahwa nilai $\mathrm{p}<$ 0,01 yang berarti ada korelasi yang positif dan signifikan antara layanan penyaluran dengan penyesuaian diri.

Berdasarkan pada pengujian hipotesis didapat korelasi antara layanan informasi digital dengan penyesuaian diri (karakter kemandirian). Maksudnya semakin sering layanan informasi digital yang diberikan kepada peserta didik IPS di SMA N 2 Bantul Yogyakarta maka mempengaruhi penyesuaian diri (karakter kemandirian) peserta didik. Layanan informasi digital yang sesuai dengan kebutuhan peserta didik IPS telah diberikan secara intensif serta peserta didik IPS dapat menerima dan memahami informasi tersebut, maka peserta didik akan memiliki penyesuaian diri (karakter kemandirian) yang baik. Demikian pula sebaliknya, apabila pemberian layanan informasi digital yang peserta didik IPS butuhkan kurang sesuai dengan kebutuhan mereka, maka peserta didik IPS akan kesulitan dalam penyesuaian diri mereka untuk memilih perguruan tinggi yang di minati.

Layanan informasi digital dapat memberikan gambaran pada peserta didik tentang tindak dan perilaku yang baik di sekolah maupun di lingkungan sekitar. Oleh karena itu layanan informasi digital mempunyai peranan penting agar peserta didik IPS dapat berperilaku dan bertindak baik sehingga siswa mampu dalam menyesuaikan diri dengan lingkungan di sekolah maupun di lingkungan sekitar.

Layanan informasi digital adalah membekali individu dengan berbagai pengetahuan tentang lingkungan yang diperlukan untuk memecahkan masalah yang dihadapi berkenaan dengan lingkungan sekitar, pendidikan, jabatan maupun sosial-budaya (Suma, et al, 2014)

Z. Mohammadi, et al, (2016) menjaelaskan bahwa layanan informasi digital sangatlah penting untuk membekali para siswa dengan pengetahuan tentang data dan fakta di bidang pendidikan sekolah, bidang pekerjaan dan bidang perkembangan pribadi-sosial, supaya mereka dapat belajar tentang lingkungan hidupnya serta lebih mampu mengatur dan merencanakan kehidupannya sendiri. 
Hasil penelitian yang dilakukan memiliki persamaan dan perbedaan dengan riset Lestari (2014), penelitian Istiah (2015), riset Fakhriyah, Roysa, dan Sumaji (2014), penelitian Ismaya dan Romadlon (2017), riset Ardianti, Wanabuliandari, dan Kanzunnudin (2019) serta penelitian . Pratiwi dan Kuryanto (2019). Persamaan yang dimaksud yaitu pada pemilihan fokus penelitian mengenai layanan informasi dan pembentukan karakter. Adapun perbedaannya terdapat pada hasil riset.

Penelitian Istiah (2015) menunjukkan ada peningkatan Kemantapan siswa dalam menentukan pilihan program studi sebanyak $84,37 \%$ sedangkan yang belum meningkat $15,63 \%$ Dari hasil observasi oleh kolaborator menunjukkan bahwa siswa sangat antusias mengikuti layanan ini mulai dari pertemuan pertama sampai pertemuan terakhir. Guru BK selaku peneliti menunjukkan keseriusan dan menyampaikan materi secara sistimatis serta selalu meningkatkan kemampuan dalam melakukan layanan informasi dengan disertai Penggunaan multi media secara optimal mulai pertemuan 1 sampai dengan pertemuan terakhir atau ke 4 Dari Laiseg juga menunjukkan peningkatan kemantapan siswa secara bertahap, dengan gambaran Pertemuan pertama 21, $87 \%$, Pertemuan kedua $37.50 \%$, Pertemuan ketiga $62,50 \%$, pertemuan keempat $84,38 \%$.

Mengenai pembentukan karakter maka penelitian Lestari (2014) menunjukkan bahwa media bimbingan dan konseling berbasis Islami yang dikembangkan dapat merangsang dan meningkatkan kemandirian siswa dalam suasana bermain yang menyenangkan. Selanjutnya riset Fakhriyah, Roysa, dan Sumaji (2014) menunjukkan adanya pengaruh positif sebagai dampak mengimplementasikan pembelajaran tematik berwawasan multiple intellegence terhadap hasil belajar dan karakter siswa. Rata-rata hasil belajar kelompok eksperimen lebih tinggi daripada kelompok kontrol. Siswa juga merasa senang karena pembelajaran yang dilakukan sesuai dengan kecerdasan yang mereka miliki. Karakter yang ikut terbentuk dalam pembelajaran ini meliputi karakter demokratis, rasa ingin tahu, mandiri dan tanggung jawab.

Lebih lanjut penelitian Ardianti, Wanabuliandari, dan Kanzunnudin (2019) menunjukkan bahwa skor karakter cinta tanah air siswa sesudah pembelajaran lebih tinggi yaitu mencapai 12,54 dibandingkan dengan sebelum pembelajaran dengan skor sebesar
6,36. Hasil analisis normalized gain diketahui bahwa tingkat peningkatan karakter cinta tanah air siswa pada kategori rendah sebesar 4,55\%, kategori sedang 40,91\%, dan kategori tinggi sebesar 54,54\%. Secara klasikal diperoleh nilai normalized gain $\langle g\rangle$ sebesar $72 \%$ atau 0,72 yang berarti tafsiran peningkatan karakter cinta tanah air termasuk kategori tinggi. Riset Ismaya dan Romadlon (2017) menyimpulkan bahwa upaya Ambalan Kyai Mojo-Nyi Ageng Serang untuk tampil dan turut serta dalam mengawal pembentukan karakter semangat kebangsaan dengan caranya sendiri. perlu mendapat perhatian segenap pihak, dan perlu diteladani oleh segenap pihak yang peduli akan masa depan bangsa Indonesia., serta Pratiwi dan Kuryanto (2019) menyimpulkan permainan tradisional betengan memiliki korelasi kuat terhadap gerak lokomotor dan karakter bersahabat siswa.

\section{SIMPULAN}

Layanan informasi digital sangat penting karena dengan pemberian layanan informasi digital yang intensif dan kontinu sesuai dengan kebutuhan peserta didik maka peserta didik IPS akan memiliki pemahaman yang jelas mengenai beberapa aspek yang ada pada dirinya dengan demikian apabila peserta didik telah memahami beberapa aspek yang ada pada dirinya, maka akan berpengaruh terhadap peningkatan penyesuaian diri (karakter kemandirian) peserta didik yang baik.

Pemberian pengarahan mengenai layanan informasi digital yang tepat sesuai dengan kondisi pribadi peserta didik, maka peserta didik IPS tersebut akan memiliki pemahaman yang jelas dan sesuai mengenai potensi yang peserta didik miliki, dengan demikian apabila peserta didik IPS dapat mengembangkan potensi sesuai dengan bakat dan minat, maka peserta didik akan memiliki karakter kemandirian yang baik terhadap kesesuaian pemilihan perguruan tiggi yang peserta didik harapkan sesui dengan minat dan bakatnya.

Berdasarkan hal diatas, maka sekolah memiliki peran penting dalam memberikan suatu informasi yang dibutuhkan peserta didik dan pengarahan penyaluran dalam hal bakat, minat, serta potensi yang peserta didik miliki sehingga akan berpengaruh terhadap meningkatnya sikap penyesuaian diri (karakter kemandirian) peserta didik yang baik. 


\section{UCAPAN TERIMA KASIH}

Penulis ucapkan terimakasih kepada SMA N 2 Bantul dan kepala Dinas Pendidikan Bantul, Yogyakarta, Indonesia yang telah memberikan ijin untuk melakukan penelitian. Penulis ucapkan terima kasih kepada Lembaga Penelitian dan Pengabdian Masyarakat (LPPM) Universitas PGRI Yogyakarta dan tim AJIB (Akselerasi Jurnal Bereputasi) yang telah banyak memberikan kritik dan saran sehingga artikel ini dapat terselesaikan dengan sempurna.

\section{DAFTAR PUSTAKA}

Ardianti, Sekar Dwi., Wanabuliandari, Savitri., dan Kanzunnudin, Moh. 2019. Implementasi Pembelajaran Berbasis Ethno-Edutainment Untuk Meningkatkan Karakter Cinta Tanah Air Siswa Sekolah Dasar. Refleksi Edukatika : Jurnal Ilmiah Kependidikan, 9 (2): 204-209.

Arikunto, Suharismi. 2010. Prosedur Penelitian. Jakarta : Rineka Cipta.

Bade Sai Kumar. 2019. Experimental Investigation To Enhance The Performance Of Heat Exchanger By Varying The Geometry Of Fin And Cooling Media. International Journal Of Scientific \& Technology Research, 8 (12).

B. Jadhavar and T. Sontakke. 2011. "Simulation and Analysis of UWB Indoor Channel Through S-V Model for User Location Detection". International Journal of Computer and Electrical Engineering, 729-738.

Fakhriyah, Fina., Roysa, Mila., dan Sumaji. 2014. Penerapan Pembelajaran Tematik Berwawasan Multiple Intellegence Dalam Upaya Membentuk Karakter Siswa di SD IT AL Islam Kudus. Refleksi Edukatika : Jurnal Ilmiah Kependidikan, 4 (1).

Ismaya, Erik Aditia dan Romadlon, Farid Noor. 2017. Strategi Membentuk Karakter Semangat Kebangsaan Anggota Ambalan Kyai Mojo dan Nyi Ageng Serang. Refleksi Edukatika : Jurnal Ilmiah Kependidikan, 7 (2): 140144.
Istiah. 2015. Layanan Informasi Berbasis Pengukuran Psikologi Untuk Kemantapan Pemilihan Studi Lanjut Siswa Kelas XII IPA 5 SMAN 1 Bae Kudus Tahun 2014 / 2015. Refleksi Edukatika : Jurnal Ilmiah Kependidikan, 5 (1).

Lestari, Indah. 2014. Pengembangan Media Bimbingan dan Konseling Berbasis Islami Untuk Membentuk Karakter Mandiri Anak Usia Dini. Refleksi Edukatika : Jurnal Ilmiah Kependidikan, 4 (1).

J.M.P. Martinez, R.B. Llavori, M.J.A. Cabo, and T.B. Pedersen. 2007. "Integrating Data Warehouses with Web Data: A Survey". Proceedings IEEE Trans. Knowledge and Data Eng.

Pratiwi, Ika Ari dan Kuryanto, Mohammad Syaffruddin. 2019. Correlation Betengan Traditional Games On Locomotor Movements And Characters. Refleksi Edukatika : Jurnal Ilmiah Kependidikan, 10 (1): 71-76.

Rajanandhini, et al. 2019. Evaluation Of The Performance Of UWB MB-OFDM System Under Four Indoor Channel Models Of IEEE802.15.4a Under Noisy Channel Conditions. International Journal Of Scientific \& Technology Research, 8 (12).

Sjukur, Sulihin. 2012. Pengaruh Blended Learning Terhadap Motivasi Belajar dan Hasil Belajar Siswa Tingkat SMK. Jurnal Pendidikan Vokasi, 2 (3).

Suma, et al. 2014. Pengaruh Penggunaan Media Video Youtube Dalam Pembelajaran IPA Terhadap Motivasi Belajar Dan Pemahaman Konsep Siswa. e-Journal Program Pascasarjana Universitas Pendidikan Ganesha Program Studi IPA, 4.

Z. Mohammadi, A. Rouijel and R. Saadane. 2016. "Performance Evaluation of MBOFDM UWB Systems Based on Optimization Algorithm for CP Decomposition". Public Administration and Information Technology: 413-421. 